\title{
Abscisic Acid Impacts Tomato Carotenoids, Soluble Sugars, and Organic Acids
}

\author{
T. Casey Barickman ${ }^{1,3}$, Dean A. Kopsell ${ }^{2}$, and Carl E. Sams ${ }^{2,4}$ \\ Plant Sciences Department, The University of Tennessee, Knoxville, TN \\ 37996
}

Additional index words. calcium, phytonutrients, carbohydrates, greenhouse, hydroponics

\begin{abstract}
Plant growth regulators (PGRs) are chemicals used on a wide range of horticultural crops. These exogenous chemicals, similar to endogenous plant hormones, regulate plant development and stimulate a desired growth response, such as control of plant height. One such PGR is abscisic acid (ABA), which has been used effectively to improve fruit quality, specifically sugars and phytonutrients. The purpose of this study was to examine the effects of exogenous applications of ABA on tomato (Solanum lycopersicum) fruit quality, such as carotenoids, soluble sugars and organic acids, and ABA on tomato leaf chlorophylls and carotenoids. Furthermore, this study compared how ABA and calcium (Ca) treatments together affect fruit quality and whether there are added benefits to treating plants with both simultaneously. ABA treatments proved effective in increasing tomato fruit soluble sugars and decreasing organic acid concentrations. This study demonstrated that ABA is a viable PGR to significantly improve tomato fruit quality, specifically pertaining to carotenoids, soluble sugar, and organic acid concentrations.
\end{abstract}

PGRs are synthetic chemicals that are used on a wide range of horticultural crops and regulate plant development to stimulate a desired metabolic response, such as controlling plant height. In the floriculture industry PGRs are typically used to control plant height and promote flower initiation or to delay bloom (Blanchard and Runkle, 2007; Curry and Erwin, 2012; Lewis et al., 2004). For example, uniconazole is used to inhibit plant growth and has been demonstrated to be effective in tomato (S. lycopersicum) transplant production (Shin et al., 2009). In addition, previous research has demonstrated that ABA can be used as a PGR in watermelon (Cucumis melo) and peppers (Capsicum annuum) to control transplant height (Shinsuke and Leskovar, 2014a, 2014b). In the nursery industry PGRs can improve crop quality by stimulating lateral branching, as a substitution for a cold storage requirement, and control plant height (Clough et al., 2001; Gibson and Whipker, 2003; Latimer et al.,

\footnotetext{
Received for publication 18 June 2015. Accepted for publication 10 Sept. 2015 .

The cost of publishing this paper was defrayed in part by the payment of page charges. Under postal regulations, this paper therefore must be hereby marked "advertisement" solely to indicate this fact. This research was made possible through support from the University of Tennessee, Institute of Agriculture, Agricultural Experiment Station.

${ }^{1}$ Research Associate/Graduate Research Assistant. ${ }^{2}$ Professor.

${ }^{3}$ Current address: Assistant Research and Extension Professor, North Mississippi Research and Extension Center, Mississippi State University, Verona, MS 38879.

${ }^{4}$ Corresponding author. E-mail: carlsams@utk.edu.
}

2003). Traditionally, in the fruit industry PGRs have been used for thinning flower blossoms to achieve larger fruit and to improve fruit firmness and nutritional quality (Greene et al., 2011; Jones et al., 1991; Meland et al., 2011). The PGR 6-benzyladenine, used in apple (Malus domestica) and pear (Pyrus communis) production, is effective in inducing flower thinning and increasing return bloom (Stopar et al., 2009).

Applications of PGRs can manipulate plant growth and development and has been evaluated for many years in horticultural crops. However, research in recent years focused on using PGRs to improve fruit quality parameters, such as soluble sugars, fruit color, and phytonutrients (Buran et al., 2012; Gonzalez et al., 2012; Gu et al., 2011; Zhang and Whiting, 2013). One such PGR is ABA, which has been used effectively to improve fruit quality, especially in grape (Vitis vinifera) production (Peppi et al., 2006). ABA has significantly increased soluble sugars in grapes, thereby improving fruit flavor. In addition, ABA also improved fruit color adding to the visual aesthetics and nutritional value (Quiroga et al., 2009). Previous research has demonstrated that $\mathrm{ABA}$ particularly increases anthocyanins (Cantin et al., 2007) and carotenoids (Barickman et al., 2014a) in fruit tissue. Based upon many studies, it has been suggested that anthocyanin compounds possess anti-inflammatory and anticarcinogenic activity (He and Giusti, 2010). In addition, carotenoids are powerful antioxidants linked to inhibiting cancers such as prostate (Giovannucci et al., 1995), skin (Gonzalez et al., 2003), and colon (Slattery et al., 1999). Organic acids, such as malic and citric, and soluble sugars, such as fructose and glucose, contribute to the characteristic tomato flavor. Sugar to acid ratios play an important part in tomato fruit flavor quality. In general, tomato fruit quality is determined by color, texture, and flavor (Azodanlou et al., 2003).

The improvement in fruit and vegetable quality parameters and the demand for healthier produce have sparked additional research in other horticultural crops. These studies indicated that in addition to PGRs, manipulating environmental factors might contribute to improve fruit quality parameters, specifically flavor and phytonutrients. Barickman et al. (2013) observed that manipulating mineral nutrients found in soils affected nutritional quality in Brassica species. They found that supplementing adequate selenium in fertilizer solutions maintained glucosinolate concentrations at beneficial levels for human nutrition. Therefore, manipulating environmental factors in addition to PGRs may significantly improve crop quality.

The purpose of this study was to examine the effects of exogenous applications of ABA on tomato fruit quality parameters, such as carotenoids, soluble sugars, and organic acids. This study also examined the effects of ABA on tomato leaf chlorophylls and carotenoids. ABA treatments were applied foliarly and through the root because previous research indicated that both exogenous applications can be effective in improving fruit quality (Barickman et al., 2014a, 2014b, 2014c, 2014d). In addition, $\mathrm{Ca}$ fertilizer concentrations were manipulated because $\mathrm{Ca}$ treatments can affect tomato fruit quality parameters (de Freitas et al., 2013). Strengthening cell walls and plant tissue is largely due to $\mathrm{Ca}$ bound as pectate in the middle lamella. Application of $\mathrm{Ca}$ during plant growth may improve firmness in fruits by increasing the number of pectin cross linkages in the middle lamella and cell wall thus increasing fruit quality (Marschner, 1995). Previous research has also indicated that ABA treatments affect the uptake, partitioning, and distribution of $\mathrm{Ca}$ in vegetative and fruit tissue in tomato (Barickman et al., 2014b, 2014c, 2014d). Bastias et al. (2011) indicated that endogenous levels of ABA effects the modulation of organic acids and sugar content in tomato fruits. Furthermore, previous research conducted by Barickman et al. (2014a) indicated that exogenous application of ABA to tomato plants can affect the carotenoid concentrations in fruit tissue. Thus, since differing levels of $\mathrm{Ca}$ and endogenous and exogenous levels of ABA affect fruit quality, this study compared how the combination of ABA and $\mathrm{Ca}$ treatments affect vegetative tissue and fruit quality parameters and whether there are added benefits to treating plants with both simultaneously.

\section{Materials and Methods}

Plant culture and harvest. Seeds of 'Mountain Fresh Plus' tomato (Johnny's Selected Seed, Waterville, ME) were sown 
into Pro-Mix BX soilless medium (Premier Tech Horticulture, Québec, Canada) and germinated in greenhouse conditions (Knoxville, TN; $35^{\circ} \mathrm{N}$ lat.) at $25 / 20 \pm 3{ }^{\circ} \mathrm{C}$ (day/ night). Natural photoperiod and intensity of sunlight for tomato production in the greenhouse were supplemented with 24 individual $1000 \mathrm{~W}$ high pressure sodium lights under a 16-h photoperiod. The lights delivered an average of $900 \mu \mathrm{mol} \cdot \mathrm{m}^{-2} \cdot \mathrm{s}^{-1}$ over the entire photoperiod. Light intensity readings were taken at $1.22 \mathrm{~m}$ off the ground. At $30 \mathrm{~d}$ after seeding, the plantlets were transferred to 11L Dutch pots (Tek Supply, Dyersville, IA) filled with Sunshine Pro Soil Conditioner (Sungro Horticulture, Agawam, MA). Tomato plants were grown hydroponically with a tomato fertilization program developed at the University of Tennessee. Elemental concentrations of the nutrient solutions were $\left(\mathrm{mg} \cdot \mathrm{L}^{-1}\right)$ : nitrogen $(\mathrm{N} ; 180)$, phosphorus $(\mathrm{P}$; 93.0), potassium $(\mathrm{K} ; 203.3)$, magnesium (Mg; 48.6), sulfur (S; 96.3), iron (Fe; 1.0), boron $(\mathrm{B} ; 0.25)$, manganese $(\mathrm{Mn} ; 0.25)$, zinc (Zn; 0.025), copper (Cu; 0.01), and molybdenum (Mo; 0.005). There were two identical experiments conducted. The first experiment was conducted in Fall 2012 and replicated in Spring 2013. Experimental design was a randomized complete block with a $3 \times 4$ factorial which consisted of six blocks and two replications, with in each block, with individual pots representing an experimental unit. $\mathrm{Ca}$ was applied as calcium nitrate at three different treatment levels of 60,90 , and 180 $\mathrm{mg} \cdot \mathrm{L}^{-1}$. Ca treatments were applied to the plants via the irrigation lines and were initiated at time of transplanting the tomato plants into the containers. The one control and three $\mathrm{ABA}$ treatments were applied either as no ABA, foliar, root, or a combination of a foliar and root applications. For foliar ABA applications, treatments consisted of deionized (DI) water control $(0 \mathrm{mg}$ $\left.\mathrm{ABA} \cdot \mathrm{L}^{-1}\right)$ or $500 \mathrm{mg}$ ABA. $\mathrm{L}^{-1}$ spray application. For ABA root applications, treatments consisted of a DI water control $(0 \mathrm{mg}$ $\mathrm{ABA} \cdot \mathrm{L}^{-1}$ ) or $50 \mathrm{mg} \mathrm{ABA} \cdot \mathrm{L}^{-1}$ applied via the irrigation lines. ABA spray treatments were applied once weekly till dripping from the foliage, while root applications were applied four times per day with the irrigation cycle. ABA treatments were initiated that anthesis and applied to tomato plants for 12 weeks. Fruit were harvested when red ripe. Subsequently, fruit were sorted by the use of United States Department of Agriculture tomato color for red ripe (USDA, 1975) and size classification into extralarge, large, medium and small (USDA, 2007). Tomato fruit with blossom-end rot were categorized separately. Fruit from each treatment were separated by replication and weighed for biomass. At least three fruit from each of two clusters from individual plants for each experimental unit were chosen randomly, frozen and prepared for organic acid, soluble sugars, and carotenoid analyses. Harvested fruit samples were stored at $-80{ }^{\circ} \mathrm{C}$ before analysis. Leaf samples were taken above each of the two clusters at the last harvest for analysis of carotenoids and chlorophylls.

Fruit carotenoid tissue determination. Carotenoids were extracted from freshfrozen ripe fruit tissues and quantified according to the methods of Emenhiser et al. (1996) with slight modifications from Barickman et al. (2014a). Briefly, fruit was removed from $-80{ }^{\circ} \mathrm{C}$ and thawed until slightly pliable. A subsample of six ripe fruits from each experimental unit (treatment) was blended into a slurry. A 2.0-g subsample of the slurry was placed into a test tube $(20 \times$ $150 \mathrm{~mm}$ ), and $5 \mathrm{~mL}$ of hexane and $0.8 \mathrm{~mL}$ of the internal standard (ethyl- $\beta-8^{\prime}$-apocarotenoate; CaroteNature GmbH, Lupsingen, Switzerland) were added. Test tubes were vortexed for $1 \mathrm{~min}$ before addition of $5 \mathrm{~mL}$ of tetrahydrofuran then vortexed for $1 \mathrm{~min}$ before additions of $5 \mathrm{~mL}$ of reverse osmosis (RO) water. After vortexing for $20 \mathrm{~s}$, test tubes were stored at $4{ }^{\circ} \mathrm{C}$ for $10 \mathrm{~min}$ to achieve aqueous-organic separations. Tubes were then centrifuged at $500 g_{n}$ for $10 \mathrm{~min}$. The organic top layer was removed using a disposable Pasteur pipette and placed into a graduated conical test tube. The sample volume was reduced to dryness under a stream of nitrogen gas (N-EVAP 111; Organomation Inc., Berlin, MA). Samples were brought up to a final volume of $5 \mathrm{~mL}$ with acetone, and a 2-mL aliquot was filtered through a $0.2-\mu \mathrm{m}$ polytetrafluoroethylene (PTFE) filter (Econofilter PTFE 25/20; Agilent Technologies, Santa Clara, CA) before high-performance liquid chromatography (HPLC) analysis.

An HPLC unit with a photodiode array detector (1200 series, Agilent Technologies) was used for pigment separation. Chromatographic separations were achieved using an analytical scale $(250 \times 4.6 \mathrm{~mm}$ i.d. $) 5-\mu \mathrm{m}$ polymeric $\mathrm{RP}^{-\mathrm{C}_{30}}$ column (ProntoSIL; MAC-MOD Analytical Inc., Chadds Ford, PA), which allowed for effective separation of chemically similar pigment compounds. The column was equipped with a $5-\mu \mathrm{m}$ guard cartridge $(10 \times 4.0 \mathrm{~mm}$ i.d. $)$ and holder (ProntoSIL), and was maintained at $40{ }^{\circ} \mathrm{C}$ using a thermostatted column compartment. All separations were achieved isocratically using a binary mobile phase of $38.00 \%$ methyl tert-butyl ether (MTBE), $61.99 \%$ methanol $(\mathrm{MeOH})$, and $0.01 \%$ triethylamine (TEA) $(\mathrm{v} / \mathrm{v} / \mathrm{v})$. The flow rate was 1.0 $\mathrm{mL} \cdot \mathrm{min}^{-1}$, with a run time of $40 \mathrm{~min}$. Eluted compounds from a $10-\mu \mathrm{L}$ injection loop were detected at $453 \mathrm{~nm}$; and data were collected, recorded, and integrated using ChemStation Software ver. B.01.01 (Agilent Technologies). Peak assignment for individual pigments was performed by comparing retention times and line spectra obtained from photodiode array detection using external standards of $\beta$-carotene (BC), lutein (LUT), and lycopene (LYCO) (ChromaDex Inc., Irvine, CA).

Leaf carotenoid and chlorophyll determination. The frozen tomato leaf samples were lyophilized in a programmed freeze dryer (Model 6L FreeZone, LabConCo,
Kansas City, MO) starting at $-40{ }^{\circ} \mathrm{C}$ for $72 \mathrm{~h}$, rising $5^{\circ} \mathrm{C}$ until $0{ }^{\circ} \mathrm{C}$. Freeze-dried tissues were then ground in liquid nitrogen with a mortar and pestle. Pigments were extracted from freeze-dried tissues according to Kopsell et al. (2004). A $0.1 \mathrm{~g}$ tissue subsample was rehydrated with $0.8 \mathrm{~mL}$ of $\mathrm{H}_{2} \mathrm{O}$ for 20 min. After incubation, $0.8 \mathrm{~mL}$ of the internal standard ethyl- $\beta-8^{\prime}$-apo-carotenoate (Sigma Chemical Co., St. Louis, MO) was added to determine extraction efficiency. The addition of $2.5 \mathrm{~mL}$ of tetrahydrofuran was performed after sample hydration. The sample was then homogenized in a Potter-Elvehjem (Kontes, Vineland, NJ) tissue grinding tube using $\approx 25$ insertions with a pestle attached to a drill press set at $13 g_{\mathrm{n}}$. During homogenization, the tube was immersed in ice to dissipate heat. The tube was then placed into a clinical centrifuge for $3 \mathrm{~min}$ at $500 \mathrm{~g}_{\mathrm{n}}$. The supernatant was removed, and the sample pellet was resuspended in 2-mL THF and homogenized again with the same extraction technique. The procedure was repeated for a total of four extractions to obtain a colorless supernatant. The combined supernatants were reduced to $0.5 \mathrm{~mL}$ under a stream of nitrogen gas (N-EVAP 111; Organomation Inc., Berlin, MA), and brought up to a final volume of $5 \mathrm{~mL}$ with $\mathrm{MeOH}$. A 2-mL aliquot was filtered through a $0.2-\mu \mathrm{m}$ PTFE filter using a 5-mL syringe before HPLC analysis.

Pigments were analyzed according to Kopsell et al. (2007). An Agilent 1200 series HPLC unit with a photodiode array detector was used for pigment separation. Chromatographic separations were achieved using an analytical scale $(4.6 \mathrm{~mm}$ i.d. $\times 250 \mathrm{~mm})$ $5 \mu \mathrm{m}, 200 \AA$ polymeric $\mathrm{RP}-\mathrm{C}_{30}$ column (ProntoSIL, MAC-MOD Analytical Inc., Chadds Ford, PA), which allowed for effective separation of chemically similar pigment compounds. The column was equipped with a $5-\mu \mathrm{m}$ guard cartridge $(4.0 \mathrm{~mm}$ i.d. $\times 10 \mathrm{~mm})$ and holder (ProntoSIL), and was maintained at $30{ }^{\circ} \mathrm{C}$ using a thermostatted column compartment. All separations were achieved isocratically using a binary mobile phase of $11 \% \mathrm{MTBE}, 88.99 \% \mathrm{MeOH}$, and $0.01 \%$ TEA $(\mathrm{v} / \mathrm{v} / \mathrm{v})$. The flow rate was $1.0 \mathrm{~mL} \cdot \mathrm{min}^{-1}$, with a run time of $53 \mathrm{~min}$, followed by a 2-min equilibration before the next injection. Eluted compounds from a $10-\mu \mathrm{L}$ injection were detected at 453 (carotenoids and internal standard), 652 [chlorophyll $a(\mathrm{Chl} a)$ ], and 665 [chlorophyll $b(\mathrm{Chl} b)] \mathrm{nm}$, and data were collected, recorded, and integrated using ChemStation Software. Peak assignment for individual pigments was performed by comparing retention times and line spectra obtained from photodiode array detection using external standards [BC, Chl $a, \mathrm{Chl} b$, LUT, neoxanthin (NEO), violaxanthin (VIO), zeaxanthin (ZEA) from ChromaDex Inc., Irvine, CA].

Soluble sugar analysis. Tomato fruit samples were ground in a bullet grinder (Homeland Houseware, LLC) for homogenous subsamples. A 2.0-g subsample was extracted in a $15-\mathrm{mL}$ test tube by adding $2 \mathrm{~mL}$ of $\mathrm{RO}$ water, vortexed, and shaken for $15 \mathrm{~min}$ at 
$200 \mathrm{rpm}$. Samples were then centrifuged at $500 g_{\mathrm{n}}$ for $10 \mathrm{~min}$ and $1.0 \mathrm{~mL}$ of the supernatant was transferred into a new $15-\mathrm{mL}$ test tube. After the transfer, $1.4 \mathrm{~mL}$ of acetonitrile were added; tubes were mixed by inversion and kept at room temperature for $30 \mathrm{~min}$. Samples were then centrifuged at $500 g_{n}$ for $10 \mathrm{~min}$, and $1.0 \mathrm{~mL}$ of the supernatant was transferred into a new $15-\mathrm{mL}$ tube and placed into a dry-bath until complete evaporation. Once dried, samples were dissolved in $0.5 \mathrm{~mL}$ of $75 \%$ acetonitrile and $25 \% \mathrm{RO}$ water. Samples were then put through a $0.2-\mu \mathrm{m}$ syringe filter and collected in a 2-mL HPLC vial for analysis. Separation parameters and sugar quantification were carried out with authentic standards using an Agilent 1100 series HPLC with a refractive index detector (Agilent Technologies). Chromatographic separations were achieved using a $250 \times$ $4.6 \mathrm{~mm}$ i.d., $5-\mu \mathrm{m}$ analytical scale amino $\left(\mathrm{NH}_{2}\right)$ carbohydrate $\mathrm{C}_{18}$ reverse-phase column (Agilent Technologies), which allowed for effective separation of chemically similar sugar compounds. The column was equipped with a Zorbax $\mathrm{NH}_{2} 4.6 \times 12.5 \mathrm{~mm}$ i.d. guard cartridge and holder (Agilent Technologies), and was maintained at $30^{\circ} \mathrm{C}$ using a thermostated column compartment. All separations were achieved isocratically using a binary mobile phase of $75 \%$ acetonitrile and $25 \%$ RO water $(\mathrm{v} / \mathrm{v})$. The flow rate was $1.0 \mathrm{~mL} \cdot \mathrm{min}^{-1}$, with a run time of $15 \mathrm{~min}$, followed by a 2-min equilibration before the next injection. Eluted compounds from a $10-\mu \mathrm{L}$ injection loop were detected in positive detection mode, and data were collected, recorded, and integrated using ChemStation Software. Peak assignment for individual sugars was performed by comparing retention times from the refractive index detector using external standards of fructose and glucose (Sigma-Aldrich, St. Louis, MO).

Organic acid analysis. A 20-g subsample of three fresh tomato fruit were frozen at $-80{ }^{\circ} \mathrm{C}$ freezer until processing for organic acid extraction. Tomato fruit were then homogenized with mortar and pestle, and a 1.0-g sample was taken for extraction and followed the procedure of Suarez et al. (2008) with some modifications. Briefly, the $1.0 \mathrm{-g}$ subsamples was placed into a $15-\mathrm{mL}$ polypropylene centrifuge tube and mixed with $2 \mathrm{~mL}$ of $80 \%$ ethanol. Afterward, the tubes were placed in an ultrasonic bath for $5 \mathrm{~min}$. The tubes were then centrifuged for $5 \mathrm{~min}$ at $500 g_{\mathrm{n}}$. The supernatant was decanted, saved, and the pellet was extracted again as stated above. The combined supernatant was then concentrated with a nitrogen stream until dryness. Once dried, samples were dissolved in $5.0 \mathrm{~mL}$ of ultra-pure water. Samples were then put through a $0.45-\mu \mathrm{m}$ nylon syringe filter and collected in a $2-\mathrm{mL}$ HPLC vial for analysis.

Separation parameters and organic acid quantification were carried out with authentic standards using an Agilent 1200 series HPLC with a refractive index detector. Chromatographic separations were achieved using a $300 \times 7.7 \mathrm{~mm}$ i.d., $8-\mu \mathrm{m}$ analytical scale
Hi-Plex H column (Agilent Technologies), which allowed for effective separation of organic acid compounds. The column was equipped with a Zorbax $\mathrm{NH}_{2} 4.6 \times 12.5 \mathrm{~mm}$ i.d. guard cartridge and holder, and was maintained at $50{ }^{\circ} \mathrm{C}$ using a thermostatic column compartment. All separations were achieved isocratically using a mobile phase of $100 \%$ $0.1 \mathrm{M} \mathrm{H}_{2} \mathrm{SO}_{4}$ (sulfuric acid). The flow rate was $0.6 \mathrm{~mL} \cdot \mathrm{min}^{-1}$, with a run time of $15 \mathrm{~min}$, followed by a 2 -min equilibration before the next injection. Eluted compounds from a $10 \mu \mathrm{L}$ injection loop were detected in positive detection mode, and data were collected, recorded, and integrated using ChemStation Software. Peak assignment for individual organic acids was performed by comparing retention times from the refractive index detector using external standards of malic and citric acids (Sigma-Aldrich, St. Louis, MO).

Statistical analysis. The two experiments were statistically similar. Therefore, data were pooled and analyzed together for treatment means. The experimental design was a randomized complete block in a factorial arrangement. The three $\mathrm{Ca}$ treatment concentrations were subdivided into ABA and non$\mathrm{ABA}$ treated plants. Analysis of variance was used to evaluate $\mathrm{ABA}$ and $\mathrm{Ca}$ treatments on leaf chlorophylls and carotenoids, fruit carotenoids and soluble sugars using the PROC GLIMMIXED model. Statistical analysis of data was performed using SAS (Version 9.3 for Windows, SAS Institute, Cary, NC). Duncan's multiple range test $(P \leq 0.05)$ was used to differentiate between ABA and $\mathrm{Ca}$ application classifications when $F$ values were significant for main effects. Data are the average of four fruit, six blocks, and two replications per treatment application. Statistical analyses indicated there were no interactions between $\mathrm{ABA}$ and $\mathrm{Ca}$ treatments. The following results are presented individually for $\mathrm{ABA}$ treatment effects and $\mathrm{Ca}$ treatment effects on leaf chlorophylls and carotenoids and fruit tissue carotenoids, soluble sugars, and organic acids.

\section{Results}

Impact of ABA on tomato leaf carotenoids and chlorophylls. Root ABA treatments significantly decreased leaf LUT concentrations in tomato plants (Table 1). LUT concentrations decreased from 9.23 to $7.91 \mathrm{mg} / 100 \mathrm{~g}$ fresh weight (FW) when comparing the $\mathrm{ABA}$ control treatment to the ABA root treatment. Foliar spray ABA treatment significantly increased ZEA in the leaf tissue (Table 1). ZEA changed from 0.05 to $0.10 \mathrm{mg} / 100 \mathrm{~g} \mathrm{FW}$ when comparing the ABA control treatment to the foliar spray, root, and foliar/root combination ABA treatment. This accounted for an increase of ZEA $100 \%$ in tomato leaf tissue.

ABA also had a significant, but negative impact on tomato leaf chlorophyll concentrations. Root ABA treatment decreased $\mathrm{Chl}$ $a$ and $\mathrm{Chl} b$ ) significantly in tomato leaf tissue (Table 1). Chl $a$ decreased from 84.21 to
$69.51 \mathrm{mg} / 100 \mathrm{~g} \mathrm{FW}$, and $\mathrm{Chl} b$ decreased from 31.55 to $26.14 \mathrm{mg} / 100 \mathrm{~g} \mathrm{FW}$ when comparing the ABA control treatment to the ABA root treatment.

Impact of $\mathrm{Ca}$ on tomato leaf carotenoids and chlorophylls. Ca treatment of $60 \mathrm{mg} \cdot \mathrm{L}^{-1}$ significantly increased $\mathrm{Chl} a$ concentrations in tomato leaf tissue (Table 1). Chl $a$ ranged from $68.69 \mathrm{mg} / 100 \mathrm{~g} \mathrm{FW}$ in the $180 \mathrm{mg} \cdot \mathrm{L}^{-1}$ $\mathrm{Ca}$ treatment to $77.71 \mathrm{mg} / 100 \mathrm{~g} \mathrm{FW}$ in $60 \mathrm{mg} \cdot \mathrm{L}^{-1} \mathrm{Ca}$ treatment. This accounted for an $11.61 \%$ increase in concentration of Chl $a$ in tomato leaf tissue with decreasing $\mathrm{Ca}$ treatment concentrations. However, $\mathrm{Ca}$ treatments did not affect $\mathrm{Chl} b$ concentrations in the leaf tissue (Table 1). In addition, $\mathrm{Ca}$ treatments did not affect the concentration of tomato leaf carotenoids (Table 1).

Influence of $A B A$ and $C a$ on tomato fruit carotenoids. The application of ABA had a significant impact on tomato fruit carotenoids. There were significant differences in LUT, BC, and LYCO (Table 2). LUT increased from 0.11 to $0.15 \mathrm{mg} / 100 \mathrm{~g} \mathrm{FW}$ when comparing the $\mathrm{ABA}$ control treatment to the ABA root treatment. The applications of foliar spray $\mathrm{ABA}$ treatments increased $\mathrm{BC}$ concentrations in tomato fruit tissue. BC concentrations increased from 0.29 to 0.36 $\mathrm{mg} / 100 \mathrm{~g}$ FW when comparing the ABA control treatment to the foliar spray ABA treatment. Root ABA treatments significantly decreased LYCO concentrations in the tomato fruit tissue. LYCO concentrations decreased from 6.07 to $4.91 \mathrm{mg} / 100 \mathrm{~g} \mathrm{FW}$ when comparing the foliar spray ABA treatment to the foliar spray and root combination $\mathrm{ABA}$ treatment. Ca treatments did not have a significant impact on tomato fruit carotenoid concentrations (Table 2).

Influence of $A B A$ and $C a$ on tomato soluble sugars. The application of ABA had a significant positive impact on tomato fruit soluble sugar concentrations (Table 2). Glucose increased from 13.39 to $19.19 \mathrm{mg} / 100 \mathrm{~g}$ FW when comparing the ABA control to the ABA root treatment. Glucose increased $30.2 \%$ in the tomato fruit tissue with $\mathrm{ABA}$ treatment. Fructose increased from 13.72 to $19.24 \mathrm{mg} / 100 \mathrm{~g} \mathrm{FW}$ when comparing the ABA control to the ABA root treatment. Fructose increased $28.7 \%$ in the tomato fruit tissue with $\mathrm{ABA}$ treatment. In addition, $\mathrm{Ca}$ increasing concentrations had a significant positive impact on tomato fruit soluble sugar concentrations (Table 2). Glucose increased from 15.70 to $19.29 \mathrm{mg} / 100 \mathrm{~g} \mathrm{FW}$ when comparing the 60 and $180 \mathrm{mg} \cdot \mathrm{L}^{-1} \mathrm{Ca}$ treatment. Fructose increased from 16.29 to 18.62 $\mathrm{mg} / 100 \mathrm{~g} \mathrm{FW}$ when comparing the 60 and $180 \mathrm{mg} \cdot \mathrm{L}^{-1} \mathrm{Ca}$ treatment.

Influence of $A B A$ and $C a$ on tomato fruit organic acids. The application of ABA had a significant negative impact on tomato fruit organic acid concentrations (Table 2). Malic acid decreased from 2.06 to $0.74 \mathrm{mg} / 100 \mathrm{~g}$ FW when comparing the ABA control to the ABA root treatment. Citric acid decreased from 4.07 to $1.34 \mathrm{mg} / 100 \mathrm{~g} \mathrm{FW}$ when comparing the $\mathrm{ABA}$ control to the $\mathrm{ABA}$ root treatment. $\mathrm{Ca}$ treatments did not have 
Table 1. Carotenoids and chlorophyll leaf tissue pigments in 'Mountain Fresh Plus' tomato plants grown in a greenhouse and treated with exogenous applications of abscisic acid (ABA) and calcium (Ca) in the hydroponic fertilizer solution.

\begin{tabular}{|c|c|c|c|c|c|c|c|c|}
\hline \multirow[b]{2}{*}{ Treatments } & \multicolumn{8}{|c|}{ Mean $(\mathrm{mg} / 100 \mathrm{~g} \mathrm{FW})^{\mathrm{y}, \mathrm{z}}$} \\
\hline & VIO & NEO & ANTH & LUT & ZEA & $\mathrm{BC}$ & CHLA & CHLB \\
\hline \multicolumn{9}{|l|}{$\mathrm{ABA}^{\mathrm{x}}$} \\
\hline Control & $0.46 \mathrm{a}$ & $2.46 \mathrm{a}$ & $1.23 \mathrm{a}$ & $9.23 \mathrm{a}$ & $0.05 \mathrm{~b}$ & $3.56 \mathrm{a}$ & $84.21 \mathrm{a}$ & $31.55 \mathrm{a}$ \\
\hline Foliar & $0.42 \mathrm{a}$ & $2.26 \mathrm{ab}$ & $0.99 \mathrm{~b}$ & $8.76 \mathrm{ab}$ & $0.09 \mathrm{a}$ & $3.44 \mathrm{ab}$ & $74.31 \mathrm{ab}$ & $28.99 \mathrm{a}$ \\
\hline Root & $0.42 \mathrm{a}$ & $2.04 \mathrm{~b}$ & $1.06 \mathrm{~b}$ & $7.91 \mathrm{~b}$ & $0.09 \mathrm{a}$ & $2.98 \mathrm{~b}$ & $69.51 \mathrm{~b}$ & $26.14 \mathrm{l}$ \\
\hline Foliar/Root & $0.44 \mathrm{a}$ & $2.19 \mathrm{ab}$ & $1.05 \mathrm{~b}$ & $9.01 \mathrm{a}$ & $0.10 \mathrm{a}$ & $3.41 \mathrm{ab}$ & $70.22 \mathrm{~b}$ & $29.05 \mathrm{a}$ \\
\hline$P$ value ${ }^{\mathrm{w}}$ & NS & NS & NS & $* *$ & * & NS & * & $* *$ \\
\hline \multicolumn{9}{|l|}{$\mathrm{Ca}\left(\mathrm{mg} \cdot \mathrm{L}^{-1}\right)$} \\
\hline 60 & $0.40 \mathrm{a}$ & $2.34 \mathrm{a}$ & $1.10 \mathrm{a}$ & $8.83 \mathrm{a}$ & $0.09 \mathrm{a}$ & $3.54 \mathrm{a}$ & $77.71 \mathrm{a}$ & $29.36 a$ \\
\hline 90 & $0.41 \mathrm{a}$ & $2.21 \mathrm{a}$ & $1.04 \mathrm{a}$ & $8.68 \mathrm{a}$ & $0.08 \mathrm{a}$ & $3.21 \mathrm{a}$ & $77.29 \mathrm{ab}$ & $28.91 \mathrm{a}$ \\
\hline 180 & $0.50 \mathrm{a}$ & $2.17 \mathrm{a}$ & $1.11 \mathrm{a}$ & $8.68 \mathrm{a}$ & $0.08 \mathrm{a}$ & $3.30 \mathrm{a}$ & $68.69 \mathrm{~b}$ & $28.53 a$ \\
\hline$P$ value ${ }^{\mathrm{w}}$ & NS & NS & NS & NS & NS & NS & $*$ & NS \\
\hline
\end{tabular}

$\overline{{ }^{2} \mathrm{VIO}}=$ violaxanthin; $\mathrm{NEO}=$ neoxanthin; $\mathrm{ANTH}=$ antheraxanthin; $\mathrm{LUT}=$ lutein; $\mathrm{ZEA}=$ zeaxanthin; $\mathrm{BC}=$ $\beta$-carotene; $\mathrm{CHLA}=$ chlorophyll $a ; \mathrm{CHLB}=$ chlorophyll $b$.

${ }^{\mathrm{y}}$ The standard error of the mean for $\mathrm{ABA}$ treatments was $\mathrm{VIO} \pm 0.07 ; \mathrm{NEO} \pm 0.12 ; \mathrm{ANTH} \pm 0.14 ; \mathrm{LUT} \pm$ $0.31 ; \mathrm{ZEA} \pm 0.01 ; \mathrm{BC} \pm 0.19 ; \mathrm{CHLA} \pm 4.01 ; \mathrm{CHLB} \pm 1.08$. The standard error of the mean for $\mathrm{Ca}$ treatments was $\mathrm{VIO} \pm 0.07 ; \mathrm{NEO} \pm 0.11 ; \mathrm{ANTH} \pm 0.14 ; \mathrm{LUT} \pm 0.27 ; \mathrm{ZEA} \pm 0.01 ; \mathrm{BC} \pm 0.17$; $\mathrm{CHLA} \pm$ 3.57 ; CHLB \pm 0.97 . Means within a column followed by different letters denote significant differences (Duncan's multiple range test $(P \leq 0.05)$.

${ }^{x}$ ABA treatments control $\left(0.0 \mathrm{mg} \cdot \mathrm{L}^{-1}\right)$; spray $\left(500 \mathrm{mg} \cdot \mathrm{L}^{-1}\right)$; root $\left(50 \mathrm{mg} \cdot \mathrm{L}^{-1}\right)$; spray/root $\left(500 \mathrm{mg} \cdot \mathrm{L}^{-1} /\right.$ $\left.50 \mathrm{mg} \cdot \mathrm{L}^{-1}\right)$.

${ }_{\text {wS }}, *, * *, * *$ Nonsignificant or significant at $P \leq 0.05,0.01$, or 0.001 , respectively.

Table 2. Fruit tissue carotenoid pigments in 'Mountain Fresh Plus' tomato plants grown in a greenhouse and treated with exogenous applications of abscisic acid (ABA) and calcium $(\mathrm{Ca})$ in the hydroponic fertilizer solution.

\begin{tabular}{lccccccc}
\hline & \multicolumn{7}{c}{ Mean $(\mathrm{mg} / 100 \mathrm{~g} \mathrm{FW})^{\mathrm{yz}}$} \\
\cline { 2 - 8 } & LUT & BC & LYCO & Glucose & Fructose & Malic acid & Citric acid \\
\hline ABA $^{\mathrm{x}}$ & & & & & & & \\
Control & $0.11 \mathrm{~b}$ & $0.29 \mathrm{a}$ & $5.97 \mathrm{a}$ & $13.39 \mathrm{~b}$ & $13.72 \mathrm{c}$ & $2.06 \mathrm{a}$ & $4.07 \mathrm{a}$ \\
Foliar & $0.13 \mathrm{~b}$ & $0.36 \mathrm{~b}$ & $6.07 \mathrm{a}$ & $18.74 \mathrm{a}$ & $18.32 \mathrm{ab}$ & $0.81 \mathrm{~b}$ & $1.59 \mathrm{~b}$ \\
Roots & $0.15 \mathrm{a}$ & $0.31 \mathrm{a}$ & $5.31 \mathrm{ab}$ & $19.19 \mathrm{a}$ & $19.24 \mathrm{a}$ & $0.74 \mathrm{~b}$ & $1.34 \mathrm{~b}$ \\
Foliar/Roots & $0.12 \mathrm{~b}$ & $0.30 \mathrm{a}$ & $4.91 \mathrm{a}$ & $18.15 \mathrm{a}$ & $17.76 \mathrm{~b}$ & $0.92 \mathrm{~b}$ & $1.83 \mathrm{~b}$ \\
$P$ value & $* *$ & $*$ & $*$ & $* * *$ & $* * *$ & $* * *$ & $* * *$ \\
Ca $\left(\mathrm{mg}^{\mathrm{w}} \mathrm{L}^{-1}\right)$ & & & & & & & \\
60 & $0.13 \mathrm{a}$ & $0.31 \mathrm{a}$ & $5.49 \mathrm{a}$ & $15.70 \mathrm{~b}$ & $16.29 \mathrm{~b}$ & $1.09 \mathrm{a}$ & $2.21 \mathrm{ab}$ \\
90 & $0.13 \mathrm{a}$ & $0.34 \mathrm{a}$ & $5.38 \mathrm{a}$ & $17.10 \mathrm{~b}$ & $16.88 \mathrm{~b}$ & $1.03 \mathrm{a}$ & $1.87 \mathrm{~b}$ \\
180 & $0.13 \mathrm{a}$ & $0.31 \mathrm{a}$ & $5.84 \mathrm{a}$ & $19.29 \mathrm{a}$ & $18.62 \mathrm{a}$ & $1.28 \mathrm{a}$ & $2.54 \mathrm{a}$ \\
$P$ value & NS & NS & NS & $* * *$ & $* *$ & NS & NS \\
\hline
\end{tabular}

${ }^{\mathrm{z}} \mathrm{LUT}=$ lutein; $\mathrm{BC}=\beta$-carotene; $\mathrm{LYCO}=$ lycopene.

${ }^{\mathrm{y}}$ The standard error of the mean for $\mathrm{ABA}$ treatments was $\mathrm{LUT} \pm 0.01 ; \mathrm{BC} \pm 0.04 ; \mathrm{LYCO} \pm 0.72$; glucose \pm 1.24 ; fructose \pm 1.04 malic acid \pm 1.24 ; citric acid \pm 0.24 . The standard error of the mean for Ca treatments was LUT $\pm 0.01 ; \mathrm{BC} \pm 0.02 ; \mathrm{LYCO} \pm 0.70 ;$ glucose $\pm 1.25 ;$ fructose $\pm 1.01 ;$ malic acid \pm 0.16 ; citric acid \pm 0.21 . Means within a column followed by different letters denote significant differences (Duncan's multiple range test $(P \leq 0.05)$.

${ }^{x}$ ABA treatments control $\left(0.0 \mathrm{mg} \cdot \mathrm{L}^{-1}\right)$; spray $\left(500 \mathrm{mg} \cdot \mathrm{L}^{-1}\right)$; root $\left(50 \mathrm{mg} \cdot \mathrm{L}^{-1}\right)$; spray/root $\left(500 \mathrm{mg} \cdot \mathrm{L}^{-1} /\right.$ $\left.50 \mathrm{mg} \cdot \mathrm{L}^{-1}\right)$.

wNS, ***,***Nonsignificant or significant at $P \leq 0.05,0.01$, or 0.001 , respectively.

a significant impact on tomato fruit organic acid concentrations (Table 2 ).

\section{Discussion}

The applications of ABA significantly increased ZEA in tomato leaf tissue. This confirms a previous report that foliar applications of ABA increased ZEA (Barickman et al., 2014a), which increases under environmental stress, especially light induced stress (Depka et al., 1998; Havaux and Niyogi, 1999). This study also demonstrated that no matter the application process of ABA, ZEA will increase in the leaf tissue. Foliar spray applications are just as effective as root and the combination of foliar spray and root applications of ABA. This may be due to ABA's effectiveness in creating a stress response no matter how it was
Baldermann et al. (2013) demonstrated that exogenously applied ABA decreased total carotenoids in tea (Camellia sinensis) plant flowers. These results were similar to the current study. When ABA treatments were applied to tomato plant roots only, carotenoids in the leaf tissue had a general decreasing trend. Therefore, the mixed results merit an investigation on the process of how ABA is applied to plants and the response of carotenoids in different plant tissues. Further research is required to determine the best application method and concentration to positively affect carotenoid concentrations in leaf vs. fruit tissue.

In the current study the root $\mathrm{ABA}$ treatments decreased $\mathrm{Chl} a$ and $\mathrm{Chl} b$ in tomato plant leaf tissue. This may be because ABA links environmental stress perception with the reduction of plant growth and photosynthetic capacity (Saibo et al., 2009). Thus, ABA carries the stress signal to the stomata and acts to close them, negatively affecting plant growth and photosynthetic capacity. Apart from restricting gas exchange by stomatal closure as a short-term effect of enhanced $\mathrm{ABA}$ levels, long-term ABA effects on photosynthesis include the inhibition of thylakoid formation, chlorophyll biosynthesis and Rubisco activity (Khokhlova et al., 1978; Kusnetsov et al., 1998; Lichtenthaler and Becker, 1970). Research demonstrated that exogenous applications of ABA reduce chlorophyll content and repress transcription of chloroplast genes leading to reduction in chloroplast-localized proteins that impact photosynthesis (Kusnetsov et al., 1994; Wang et al., 2010; Yamburenko et al., 2013). Thus, ABA negatively impacts the production and function of proteins in the photosynthetic process. Exogenous application of ABA in the current study may indirectly affect expression of chloroplast genes and regulate their activity leading to decreases in chlorophyll concentrations in tomato leaves. Therefore, the effect of ABA may lead to an indirect down-stream signal, such as transcription factors, that regulate chloroplast genes function and, to a larger extent, photosynthesis as a response to abiotic stress.

This study found that decreasing $\mathrm{Ca}$ treatments increased chlorophyll concentrations while not affecting leaf carotenoid concentrations. Tomato leaf chlorophyll concentrations decreased when plants were treated with Ca treatment of $180 \mathrm{mg} \cdot \mathrm{L}^{-1}$. In addition, leaf carotenoid concentrations did not change from Ca treatment of $180 \mathrm{mg} \cdot \mathrm{L}^{-1}$ to the deficient treatments of 60 and 90 $\mathrm{mg} \cdot \mathrm{L}^{-1}$. The effect of varying Ca supply on leaf chlorophyll and carotenoid concentrations has been investigated with mixed results. The differences in results may be due to plant species, stage of growth and environmental conditions. For example, varying $\mathrm{Ca}$ treatment concentrations in Arabidopsis did not impact the chlorophyll and carotenoid content in the leaves (Kaddour et al., 2012). In leaves of Cyclocarya paliurus seedlings, decreasing the $\mathrm{Ca}$ treatment concentration from 18 to $12 \mathrm{~mm}$ increased the chlorophyll concentrations (Yao and Wang, 2012). Like 
the current study, Kaddour et al. (2012) and $\mathrm{Xu}$ et al. (2013) recorded results for plants that were not under any environment stress. On the other hand, Ca treatments alleviated photoinhibition of the photosystem II by positively impacting the xanthophyll cycle pigment concentrations in peanut (Arachis hypogaea), a calciphilous plant species, during heat stress and high light conditions (2013). In addition, research has demonstrated that applications of $\mathrm{CaCl}_{2}$ treatments resulted in higher concentrations of Chl $a$ and Chl $b$ in Zoysia japonica under drought conditions (Xu et al., 2013). These studies demonstrated that $\mathrm{Ca}$ treatments may have a bigger impact on chlorophyll and carotenoid concentrations under environmental stress conditions. Previous research indicated that $\mathrm{Ca}$ has a central role in the plants' defense mechanisms that are induced by environmental stress, and $\mathrm{Ca}$ signaling is required for plants' tolerance to this stress (Cousson, 2007, 2009). In addition, Kopsell et al. (2013) demonstrated that $\mathrm{Ca}: \mathrm{Mg}$ ratios significantly affect the mineral nutrient uptake and carotenoid concentrations in kale (Brassica oleracea var. Acephala). Therefore, increasing $\mathrm{Ca}$ treatments may be able to positively regulate chloroplast genes that help to increase leaf chlorophyll and carotenoid concentrations under environmental stress.

The application of ABA affected the concentration of different carotenoids in tomato fruit tissue in a different way. LUT increased in the fruit tissue when ABA was applied in the foliar spray or root treatments when compared with the ABA control treatment. $B C$ increased in the fruit tissue when ABA was applied in the foliar spray treatment when compared with the ABA control treatment. However, LYCO concentrations in the foliar spray treatment did not differ from the ABA control treatment. LYCO did decrease when ABA was applied to the root tissue. Thus, the foliar spray applications of ABA had the greatest effect on carotenoids in tomato fruit tissue. Previous research supported the current study's findings. Research demonstrated that ABA plays an essential role in fruit ripening. For example, ABA controls ethylene production in tomato fruit (Zhang et al., 2009), leading to increases in pigmentation and carotenoid levels. Furthermore, data also indicated that ABA positively regulated the degree of pigmentation and carotenoid composition during tomato fruit ripening by acting on gene functions (Sun et al., 2012) The application of exogenous ABA to tomato plants could be a novel approach to increasing carotenoid concentrations in the fruit tissue, leading to a more nutritious tomato fruit.

The application of $\mathrm{Ca}$ treatments to tomato plants did not affect the carotenoid content in the fruit tissue. However, research demonstrated that excess $\mathrm{Ca}$ concentrations in the fruit tissue could affect the carotenoid concentrations. For example, Paiva et al. (1998) demonstrated that an increase in $\mathrm{Ca}$ concentration in the nutrient solution results in a decrease in LYCO content due to the antagonism between $\mathrm{Ca}$ and potassium. Increases in $\mathrm{Ca}$ content in plant tissue have an antagonistic effect on $\mathrm{K}$ and can reduce its absorption. Lack of $\mathrm{K}$ absorption into the fruit tissue can have a negative effect on the production of carotenoids. Research demonstrated that increases in $\mathrm{K}$ improve the quality of tomato fruit by positively influencing carotenoid biosynthesis (Ramirez et al., 2009). Therefore, in the current study, increasing the $\mathrm{Ca}$ treatment concentrations to $180 \mathrm{mg} \cdot \mathrm{L}^{-1}$ does not affect the $\mathrm{K}$ (data not shown) absorption into tomato fruit and negatively influence carotenoid concentration.

Exogenous applications of ABA positively influence soluble sugar concentrations in the fruit tissue. Previous research found similar results. Bastias et al. (2011) found that over expressing key ABA regulated genes increases soluble sugar concentrations in tomato fruit. Thus, under stressful conditions $\mathrm{ABA}$ increases, which in turn increases sugar accumulation by activating signals associated with stress responses (Saito et al., 2008). Therefore, not only will ABA increase soluble sugar accumulation under normal ripening conditions, it will also stimulate soluble sugar accumulation under stress conditions.

This study found decreases in soluble sugar concentrations in tomato fruit tissue when $\mathrm{Ca}$ treatments were decreased from $180 \mathrm{mg} \cdot \mathrm{L}^{-1}$ to $\mathrm{Ca}$ deficit levels of 60 and $90 \mathrm{mg} \cdot \mathrm{L}^{-1}$. Thus, plants treated with $\mathrm{Ca}$ concentration treatments had the highest levels of soluble sugars in the tomato fruit tissue. These findings correspond to previous research, which indicated that the addition of $\mathrm{Ca}$ as a preharvest treatment increased total soluble solids, total soluble sugars, and $\mathrm{Ca}$ in pear ( $P$. communis) fruit tissue (Omaima et al., 2010). However, in the current study there were no interactions when analyzing $\mathrm{ABA}$ and $\mathrm{Ca}$ treatments together. The increased levels of soluble sugars in the fruit tissue treated by $\mathrm{ABA}$ and $\mathrm{Ca}$ were similar, indicating that applications of either ABA or $\mathrm{Ca}$ alone would yield the same results. Applying $\mathrm{ABA}$ and $\mathrm{Ca}$ treatments together did not result in greater soluble sugar concentrations because, at low $\mathrm{Ca}$ treatments, ABA did not increase the soluble sugar concentrations in tomato fruit tissue.

Tomato plants treated with exogenous applications of ABA had decreased organic acid concentrations in the fruit tissue. Specifically, malic and citric acid decreased in tomato fruit tissue in all treatment applications of $\mathrm{ABA}$ when compared with the $\mathrm{ABA}$ control treatment. Previous research supported data that exogenous applications of ABA accelerate ethylene production leading to fruit quality changes in mango (Mangifera indica) fruit (Zaharah and Singh, 2012). In addition, Zaharah et al. (2013) found that exogenous applications of ABA promoted the activities of ethylene biosynthesis enzymes leading to fruit softening, increases in soluble sugars, and degradation of total organic acid. These experiments support the current study, which demonstrated that exogenous applications of ABA lead to an increase in carotenoids and soluble sugars and decreases in organic acids. These data indicated that ABA can improve tomato fruit quality by positively influencing the sugar to acid ratio, thereby improving the flavor and increasing the nutritional value by increasing carotenoid concentrations.

This study demonstrated that ABA can improve tomato fruit quality, specifically pertaining to carotenoids, soluble sugar, and organic acid concentrations. However, ABA applications in conjunction with low $\mathrm{Ca}$ treatments did not prove to be more effective in improving tomato fruit quality than each ABA or $\mathrm{Ca}$ treatment alone. Tomato plants still need the adequate concentration of $\mathrm{Ca}$ in the fertilizer solution in order for $\mathrm{ABA}$ to improve fruit carotenoids, soluble sugars, and decrease organic acid concentrations. The application of ABA could be a novel application of a PGR to improve overall fruit quality with adequate fertilization of the plant. The efficacy of ABA may be more an issue of application process to improve tomato fruit quality. Thus, this study indicates that foliar spray applications of ABA are a more viable choice to improve carotenoid and soluble sugar and decrease the organic acid concentrations in tomato fruit. However, further research is needed to investigate the optimum concentrations and frequency of ABA applications to the root and leaf to fine tune the impact on fruit quality.

\section{Literature Cited}

Azodanlou, R., C. Darbellayb, J.L. Luisierc, J.C. Villettazc, and R. Amadoa. 2003. Development of a model for quality assessment of tomatoes and apricots. Lebensm.-Wiss. U. Technol. 36: 223-233.

Baldermann, S., Z.Y. Yang, M. Sakai, P. Fleischmann, A. Morita, Y. Todoroki, and N. Watanabe. 2013. Influence of exogenously applied abscisic acid on carotenoid content and water uptake in flowers of the tea plant (Camellia sinensis). J. Sci. Food Agr. 93:1660-1664.

Barickman, T.C., D.A. Kopsell, and C. Sams. 2013. Selenium influences glucosinolate and isothiocyanates and increases sulfur uptake in Arabidopsis thaliana and rapid-cycling Brassica oleracea. J. Agr. Food Chem. 61:202-209.

Barickman, T.C., D.A. Kopsell, and C. Sams. 2014a. Abscisic acid increases carotenoid and chlorophyll concentrations in leaves and fruit of two tomato genotypes. J. Amer. Soc. Hort. Sci. 3:261-266.

Barickman, T.C., D.A. Kopsell, and C.E. Sams. 2014b. Foliar applications of abscisic acid decrease the incidence of blossom-end rot in tomato fruit. Sci. Hort. 179:356-362.

Barickman, T.C., D.A. Kopsell, and C.E. Sams. 2014c. Abscisic acid improves calcium partitioning into 'Micro' tomato fruit tissue. Acta Hort. 1042:113-120.

Barickman, T.C., D.A. Kopsell, and C.E. Sams. 2014d. Exogenous foliar and root applications of abscisic acid Increase the influx of calcium into tomato fruit tissue and decrease the incidence of blossom. HortScience 49: 1397-1402. 
Bastias, A., M. Lopez-Climent, M. Valcarcel, S. Rosello, A. Gomez-Cadenas, and J.A. Casaretto. 2011. Modulation of organic acids and sugar content in tomato fruits by an abscisic acidregulated transcription factor. Physiol. Plant. 141:215-226.

Blanchard, M.G. and E.S. Runkle. 2007. Dipping bedding plant liners in paclobutrazol or uniconazole inhibits subsequent stem extension. HortTechnology 17:178-182.

Buran, T.J., A.K. Sandhu, A.M. Azeredo, A.H. Bent, J.G. Williamson, and L.W. Gu. 2012. Effects of exogenous abscisic acid on fruit quality, antioxidant capacities, and phytochemical contents of southern high bush blueberries. Food Chem. 132:1375-1381.

Cantin, C.M., M.W. Fidelibus, and C.H. Crisostoc. 2007. Application of abscisic acid (ABA) at veraison advanced red color development and maintained postharvest quality of 'Crimson Seedless' grapes. Postharvest Biol. Technol. 46:237-241.

Clough, E.A., A.C. Cameron, R.D. Heins, and W.H. Carlson. 2001. Growth and development of Oenothera fruticosa is influenced by vernalization duration, photoperiod, forcing temperature, and plant growth regulators. J. Amer. Soc. Hort. Sci. 126:269-274.

Cousson, A. 2009. Involvement of phospholipase $\mathrm{C}$-independent calcium-mediated abscisic acid signalling during Arabidopsis response to drought. Biol. Plant. 53:53-62.

Cousson, A. 2007. Two calcium mobilizing pathways implicated within abscisic acid-induced stomatal closing in Arabidopsis thaliana. Biol. Plant. 51:285-291.

Curry, C.J. and J.E. Erwin. 2012. Foliar applications of plant growth regulators affect stem elongation and branching of 11 Kalanchoe species. HortTechnology 22:338-344.

de Freitas, S.T., A.J. Meelron, K.A. Shackel, and E.J. Mitcham. 2013. Calcium partitioning and allocation and blossom-end rot development in tomato plants in response to whole-plant and fruit-specific abscisic acid treatment. J. Expt. Bot. 65:235-247.

Depka, B., P. Jahns, and A. Trebst. 1998. Betacarotene to zeaxanthin conversion in the rapid turnover of the D1 protein of photosystem II. FEBS Lett. 424:267-270.

Du, H., N.L. Wang, F. Cui, X.H. Li, J.H. Xiao, and L.Z. Xiong. 2010. Characterization of the beta-carotene hydroxylase gene DSM2 conferring drought and oxidative stress resistance by increasing xanthophylls and abscisic acid synthesis in rice. Plant Physiol. 154:1304-1318.

Emenhiser, C., N. Simunovic, L.C. Sander, and S.J. Schwartz. 1996. Separation of geometrical carotenoid isomers in biological extracts using a polymeric C-30 column in reversed-phase liquid chromatography. J. Agr. Food Chem. 44:3887-3893.

Gibson, J.L. and B.E. Whipker. 2003. Efficacy of plant growth regulators on the growth of vigorous osteospermum cultivars. HortTechnology 13:132-135.

Giovannucci, E., A. Ascherio, E.B. Rimm, M.J. Stampfer, G.A. Colditz, and W.C. Willett. 1995. Intake of carotenoids and retinol in relation to risk of prostate cancer. J. Natl. Cancer Inst. 87:1767-1776.

Gonzalez, S., S. Astner, W. An, D. Goukassian, and M.A. Pathak. 2003. Dietary lutein/zeaxanthin decreases ultraviolet B-induced epidermal hyperproliferation and acute inflammation in hairless mice. J. Invest. Dermatol. 121: 399-405.
Gonzalez, A.S., P. Olea, E. Bordeu, J.A. Alcalde, and L. Geny. 2012. S-Abscisic acid, 2-chloroethylphosphonic acid and indole-3-acetic acid treatments modify grape (Vitis vinifera L. 'Cabernet Sauvignon') hormonal balance and wine quality. Vitis 51:45-52.

Greene, D.W., J.R. Schupp, and H.E. Winzeler. 2011. Effect of abscisic acid and benzyladenine on fruit set and fruit quality of apples. HortScience 46:604-609.

Gu, S., S. Jacobs, and G. Du. 2011. Efficacy, rate and timing of applications of abscisic acid to enhance fruit anthocyanin contents in 'Cabernet Sauvignon' grapes. J. Hort. Sci. Biotechnol. 86:505-510.

Havaux, M. and K.K. Niyogi. 1999. The violaxanthin cycle protects plants from photooxidative damage by more than one mechanism. Proc. Natl. Acad. Sci. USA 96:8762-8767.

He, J. and M.M. Giusti. 2010. Anthocyanins: Natural colorants with health-promoting properties. Annu. Rev. Food Sci. Technol. 1:163187.

Jones, K.M., S.A. Bound, T.B. Koen, and M.J. Oakford. 1991. Improving fruit-set on young red delicious apple-trees using autumn sprays of paclobutrazol and ethephon. J. Hort. Sci. 66:165-169.

Kaddour, R., H. Mahmoudi, O. Baatour, I. Tarchoun, N. Nasri, I. Bensaleh, P. Berthomieu, M. Gruber, and M. Lachaal. 2012. Physiological and molecular responses of two Arabidopsis accessions to calcium amendment and salt constraint. Acta Physiol. Plant. 34: 439-450.

Khokhlova, V.A., N.N. Karavaiko, T.A. Podergina, and O.N. Kulaeva. 1978. The antagonistic effect of abscisic acid and cytokinin on the structural and biochemical differentiation of chloroplasts in isolated pumpkin cotyledons. Cell Tissue Biol. 20:1033-1039.

Kopsell, D.A., T.C. Barickman, C.E. Sams, and J.S. McElroy. 2007. Influence of nitrogen and sulfur on biomass production and carotenoid and glucosinolate concentrations in watercress (Nasturtium officinale R. Br.). J. Agr. Food Chem. 55:10628-10634.

Kopsell, D.A., D.E. Kopsell, M.G. Lefsrud, J. Curran-Celentano, and L.E. Dukach. 2004. Variation in lutein, beta-carotene, and chlorophyll concentrations among Brassica oleracea cultigens and seasons. HortScience 39:361364.

Kopsell, D.A., D.E. Kopsell, T.C. Barickman, and C.E. Sams. 2013. Ratio of calcium to magnesium influences biomass, elemental accumulations, and pigment concentrations in kale. J. Plant Nutr. 36:2154-2165.

Kusnetsov, V.V., R. Oelmuller, M.I. Sarwat, S.A. Porfirova, G.N. Cherepneva, R.G. Herrmann, and O.N. Kulaeva. 1994. Cytokinins, abscisic acid and light affect accumulation of chloroplast proteins in Lupinus luteus cotyledons without notable effect on steady-state messenger RNA levels specific protein response to light/phytohormone interactions. Planta 194:318-327.

Kusnetsov, V., R.G. Herrmann, O.N. Kulaeva, and R. Oelmuller. 1998. Cytokinin stimulates and abscisic acid inhibits greening of etiolated Lupinus luteus cotyledons by affecting the expression of the light-sensitive protochlorophyllide oxidoreductase. Mol. Gen. Genet. 259:21-28.

Latimer, J.G., H.L. Scroggins, and T.J. Banko. 2003. Persistence of plant growth regulator effects on perennial plants in the nursery. Acta Hort. 624:229-232.
Lewis, K.P., J.E. Faust, J.D. Sparkman, and L.W. Grimes. 2004. The effect of daminozide and chlormequat on the growth and flowering of poinsettia and pansy. HortScience 39:13151318.

Li, Z., X. Zhao, A.K. Sandhu, and L.W. Gu. 2010. Effects of exogenous abscisic acid on yield, antioxidant capacities, and phytochemical contents of greenhouse grown lettuces. J. Agr. Food Chem. 58:6503-6509.

Lichtenthaler, H.K. and K. Becker. 1970. Inhibition of the light-induced vitamin K1 and pigment synthesis by abscisic acid. Phytochemistry 9:2109-2113.

Marschner, H. 1995. Mineral nutrition of higher plants, Academic Press, San Diego, CA.

Meland, M., L. Sakse, and C. Kaiser. 2011. Ethephon as a blossom and fruitlet thinner affects crop load, fruit weight, fruit quality, and return bloom of 'summerred' apple (Malus $\times$ domestica) Borkh. HortScience 46:432-438.

Omaima, M., H. Hamouda, and M.A. Abd-El-Mageed. 2010. Effect of calcium and some antioxidants treatments on storability of Le Conte pear fruits and its volatile components. Science 8 : 109-126.

Paiva, E.A.S., H.E.P. Martinez, V.W.D. Casali, and L. Padilha. 1998. Occurrence of blossom-end rot in tomato as a function of calcium dose in the nutrient solution and air relative humidity. J. Plant Nutr. 21:2663-2670.

Peppi, M.C., M.W. Fidelibus, and N. Dokoozlian. 2006. Abscisic acid application timing and concentration affect firmness, pigmentation, and color of 'flame seedless' grapes. HortScience 41:1440-1445.

Quiroga, A.M., F.J. Berli, D. Moreno, J.B. Cavagnaro, and R. Bottini. 2009. Abscisic acid sprays significantly increase yield per plant in vineyard-grown wine grape (Vitis vinifera L.) cv. cabernet sauvignon through increased berry set with no negative effects on anthocyanin content and total polyphenol index of both juice and wine. J. Plant Growth Regul. 28:28-35.

Ramirez, L.F., J. Muro, and P. Sanchez. 2009. Potassium affects the lycopene and beta-carotene concentration of greenhouse tomato. Acta Hort. 821:223-227.

Saibo, N.J.M., T. Lourenco, and M.M. Oliveira. 2009. Transcription factors and regulation of photosynthetic and related metabolism under environmental stresses. Ann. Bot. (Lond.) 103:609-623.

Saito, T., C. Matsukura, Y. Ban, K. Shoji, M. Sugiyama, N. Fukuda, and S. Nishimura. 2008. Salinity stress affects assimilate metabolism at the gene-expression level during fruit development and improves fruit quality in tomato (Solanum lycopersicum L.). J. Jpn. Soc. Hort. Sci. 77:61-68.

Shin, W.G., S.J. Hwang, I. Sivanesan, and B.R Jeong. 2009. Height suppression of tomato plug seedlings by an environment friendly seed treatment of plant growth retardants. Afr. J. Biotechnol. 8:4100-4107.

Shinsuke, A. and D.I. Leskovar. 2014a. Agedependent effectiveness of exogenous abscisic acid in height control of bell pepper and jalapeño transplants. Sci. Hort. 175:193-200.

Shinsuke, A. and D.I. Leskovar. 2014b. Growth reduction by exogenous abscisic acid limit the benefit of height control in diploid and triploid watermelon transplants. HortScience 49:465-471.

Slattery, M.L., S.L. Edwards, K.M. Boucher, K Anderson, and B.J. Caan. 1999. Lifestyle and 
colon cancer: An assessment of factors associated with risk. Am. J. Epidemiol. 150:869-877.

Stopar, M., G. Leskosek, and A. Simoncic. 2009. 1-Naphthaleneacetic acid and 6-benzyladenine thinning of a common slender spindle 'Jonagold'/M.9 apple orchard. I: Dose effects and spray distribution in the crowns. J. Hort. Sci. Biotech. (S):122-126.

Suarez, M.H., E.R. Rodriguez, and C.D. Romero. 2008. Analysis of organic acid content in cultivars of tomato harvested in Tenerife. Eur. Food Res. Technol. 226:423-435.

Sun, L., B. Yuan, M. Zhang, L. Wang, M.M. Cui, Q. Wang, and P. Leng. 2012. Fruit-specific RNAi-mediated suppression of SINCED1 increases both lycopene and beta-carotene contents in tomato fruit. J. Expt. Bot. 63: 3097-3108.

USDA 1975. Color classification requirements in United States Standards for grades of fresh tomatoes. USDA Visual Aid TM-L-1.
USDA 2007. United States Standards for grades of greenhouse tomatoes. USDA Agr. Marketing Serv.

Wang, X.Q., T.Y. Kuang, and Y.K. He. 2010 Conservation between higher plants and the moss Physcomitrella patens in response to the phytohormone abscisic acid: A proteomics analysis. BMC Plant Biol. 10:192-202.

Xu, C.B., X.M. Li, and L.H. Zhang. 2013. The effect of calcium chloride on growth, photosynthesis, and antioxidant responses of Zoysia japonica under drought conditions. PLoS One 8:e68214.

Yamburenko, M.V., Y.O. Zubo, R. Vankova, V.V. Kusnetsov, O.N. Kulaeva, and T. Borner. 2013. Abscisic acid represses the transcription of chloroplast genes. J. Expt. Bot. 64:4491-4502.

Yao, R.L. and Y. Wang. 2012. Optimum $\mathrm{Ca}\left(\mathrm{NO}_{3}\right)_{2}$ supply develops salt tolerance in $\mathrm{NaCl}$-stressed Cyclocarya paliurus seedlings. Hort. Environ. Biotech. 53:20-23.
Zaharah, S.S. and Z. Singh. 2012. Abscisic acid modulates mango fruit ripening. In: M.I. Cantwell and D.P.F. Almeida (eds.). Xxviii International Horticultural Congress on Science and Horticulture for People. Leuven 1: Int. Soc. Hort. Sci.

Zaharah, S.S., Z. Singh, G.M. Symons, and J.B. Reid. 2013. Mode of action of abscisic acid in triggering ethylene biosynthesis and softening during ripening in mango fruit. Postharvest Biol. Technol. 75:37-44.

Zhang, C.X. and M. Whiting. 2013. Plant growth regulators improve sweet cherry fruit quality without reducing endocarp growth. Sci. Hort. 150:73-79.

Zhang, M., B. Yuan, and P. Leng. 2009. The role of ABA in triggering ethylene biosynthesis and ripening of tomato fruit. J. Expt. Bot. 60:15791588 . 